\title{
El Güegüense
}

\section{Pablo Danilo Téllez Vado}

Licenciado en Bellas Artes. Licenciatura en Artes y Letras

https://orcid.org/0000-0001-9198-783X

pablotvnic@gmail.com

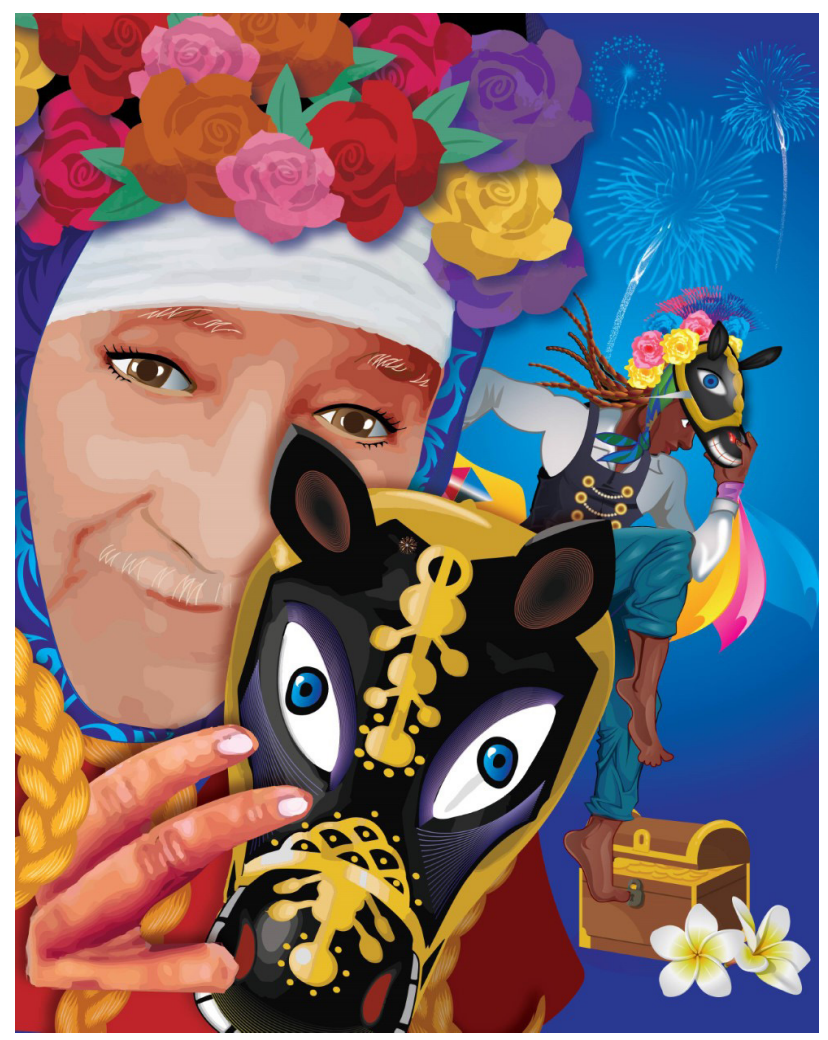

El Güegüense, Patrimonio de la Humanidad, declarado asi por la UNESCO, es un drama satírico y fue la primera obra teatral de la literatura nicaragüense, y la primera obra teatral en América. Se conservan tres manuscritos originales de la obra que incorporan texto, bailes, gestos, saltos y sones al ritmo del atabal y el pito, principalmente, pero a cuántos nos a llegado la información por la lectura a conciencia, muchos las referimos por intuición visual, gracias a los grupos de danza o en menor frecuencia los grupos de teatro. El mayor vínculo es gracias a la transmisión de esta tradición de generación a generación, como lo queremos representar en la portada, de los abuelos a los que fueron nuestros padres, que a su vez lo transmitieron a sus hijos enlazando la picardía y el ingenio de nuestro viejos de antaño a la energía y dinámica de la juventud actual. Vivamos esta tradición cultural latente durante las fiestas patronales de San Sebastián en Diriamba, Carazo, del 17 al 27 de enero y en Masaya para las fiestas de la Patrona titular de la ciudad, la Virgen de la Asunción, el 14 de agosto y también en las fiestas de San Jerónimo el 30 de septiembre, nuestra Nicaragua es única y sobre todo original.

\section{Pablo Danilo Téllez Vado}

Nacido en Managua, Nicaragua el 30 de Junio de 1964. Cursado estudios en la Escuela Nacional de Bellas Artes y Escuela Nacional de Música. Licenciado en Bellas Artes. Licenciatura en Artes y Letras. Con experiencia laboral de 40 años en diseño gráfico, dibujo artístico y publicitario, muralismo, retrato y caricatura. Ha participado en varios proyectos en Pro de la infancia, adolescencia y jóvenes en riesgo en campañas de la mano con la UNU, UNICEF, SAVE THE CHILDREN, ALDEAS SOS, JÓVENES ROMPE CABEZAS y otros organismos. Exposiciones y pinturas murales tanto a nivel nacional como en el extranjero. Ha elaborado, hasta la actualidad como Director de Arte y creatividad de la agencia hilo y de la agencia tendencias comunicación integral publicidad en campañas sociales para el cambio de comportamientos. 